\title{
Toplumterimbilimsel bir yaklaşım örneği: Ekoloji terimlerinin çevrimiçi ağlarda dolaşımı 1
}

\section{Deniz KURMEL ${ }^{2}$ Zeynep GÖRGÜLER3}

\begin{abstract}
APA: Kurmel, D.; Görgüler, Z. (2020). Toplumterimbilimsel bir yaklaşım örneği: Ekoloji terimlerinin çevrimiçi ağlarda dolaşımı. RumeliDE Dil ve Edebiyat Araştırmaları Dergisi, (18), 725736. DOI: $10.29000 /$ rumelide.706516
\end{abstract}

$\ddot{O} \mathbf{z}$

Çeviri uzmanlık alanları arasında geçmişte bulunan keskin sınırlamalar günümüzde yerini daha esnek, saydam ve geçişli yaklaşımlara bırakmaktadır. Uzmanlık alanları, çeviribilimin disiplinlerarası doğasıyla örtüşür şekilde, birbirlerinden beslenip etkilenerek alanlararası bir ortam oluşturmaktadır. Uzmanlık alanlarına yönelik terimbilimsel çözümlemelerde kavram/terim ilişkilerini ele alırken sözünü ettiğimiz esnek ve geçişli yapı belirleyici olabilmektedir. Bu noktada, alanlararası dolaşım, toplumsal hareketler, toplumsal eyleyiciler, iktidar ilişkileri ve iletişim kanalları gibi toplumsal dinamikleri göz önünde bulundurarak terimleri ele alan toplumterimbilime (Gambier, 1987, 1993; Gaudin, 1993, 2003) ilişkin yaklaşım önem kazanmaktadır. Nitekim çeviribilim alanında kültürel paradigmaya geçiş sonrası yaşanan toplumsal vurgu sonrası, toplumterimbilime ilişkin yapılan bilimsel araştırmaların sayısı da artış göstermiştir. Birçok farklı alanı besleyen, farklı alanlarla etkileşim içinde olan ekoloji alanına ait terimlerin dolaşımı, toplumterimbilimsel inceleme için önemli veriler sunmaktadır. Bu noktadan hareketle, çalışmanın amacı, yukarıda sözü edilen toplumterimbilime ilişkin kavramlar ışığında, çevrimiçi topluluklar etrafında örgütlenen eyleyicilerin terimler aracılığıyla üretip, dolaşıma soktukları toplumsal ekoloji (Bookchin, 1996) hareketinin izlerini, netnografik bir çözümlemeyle (Kozinets, 2002) sürmektir.

Anahtar kelimeler: Çeviribilim, toplumterimbilim, toplumsal ekoloji, çevrimiçi topluluklar, netnografi.

\section{Example of a socioterminological approach: Circulation of ecology terms in digital networks}

\begin{abstract}
Today, sharp limitations between specialized fields are replaced by more flexible, transparent and transitive approaches. Their specialized fields are fed and influenced by each other, creating an interdisciplinarity environment. The flexible and transitive structure that we mention can be decisive when addressing concept/term relationships in terminological analysis. At this point, the approach to socioterminology (Gambier, 1987,1993; Gaudin, 1993, 2003), which takes into consideration terms in social context such as interdisciplinary circulation, social movements, social actions, relations of
\end{abstract}

\footnotetext{
1 Bu makale, 7-8 Mart 2019 tarihinde Galatasaray Üniversitesi'nde düzenlenen XIV. Frankofoni Kongresinde sunulan bildiriden türetilmiștir.

2 Arş. Gör. Dr., Yıldız Teknik Üniversitesi, Fen edebiyat Fakültesi, Batı Dilleri ve Edebiyatları Bölümü, Fransızca MütercimTercümanlık ABD (İstanbul, Türkiye), denkocak@yahoo.fr, ORCID ID: oooo-ooo2-1041-5926 [Makale kayıt tarihi: 20.02.2020-kabul tarihi: 20.03.2020; DOI: 10.29000/rumelide.706516]

3 Arş. Gör. Dr., Yıldız Teknik Üniversitesi, Fen edebiyat Fakültesi, Batı Dilleri ve Edebiyatları Bölümü, Fransızca MütercimTercümanlı ABD (İstanbul, Türkiye), zeynepsuter@gmail.com, ORCID ID: 0ooo-0001-6538-4840
} 
power, and channels of communication, becomes important. The circulation of terms belonging to the field of ecology, which feeds many different fields and interacts with different fields, provides important data for sociterminological research. From this point on, the aim of the study is to follow the social ecology (Bookchin, 1996) movement, which is produced and put into circulation through terms by netnographic analysis (Kozinets, 2002), organized around online communities in the light of the concepts related to socioterminology mentioned above.

Keywords: Translation studies, socioterminology, social ecology, online communities, netnography.

\section{Giriş}

Günümüzde ekolojik duruş, gelişmiş ve gelişmekte olan toplumların altını çizdiği bir olgu olarak anlam kazanmaktadır. Alanlararası bir doğaya sahip olan ekoloji birçok alanla etkileşimde olan karma bir alan olarak yapılanmakta ve farklı alanlardan gelen kavramlar ekoloji bağlamında yeni tanımlar kazanmaktadır. Bu bağlamda, ekoloji alanı, kavram terim ilişkiselliğini ele alan terimbilimcilerin, özellikle de bu ilişkiselliği toplumsal boyutuyla değerlendiren toplumterimbilimcilerin dikkatini çekmektedir. Öncelikli olarak terimbilimin de alanlararası bir kimliği barındırdığını vurgulamak yerinde olacaktır; terimler hem araştırmanın gerçekleştirildiği uzmanlık alanının, hem de söz konusu uzmanlık alanında metin/içerik üretiminin veya metin/içerik çevirisinin yapı taşları konumundadır. Ekoloji alanı ise, birçok içeriğin üretildiği yeni medya ortamlarında sistematik ve hızlı bir şekilde yer bulmaktadır. Çevrimiçi toplulukların yeni medya uygulamalarında sergiledikleri ekolojik duruş bu çalışmanın çıkış noktası olarak ele alınmaktadır.

Bu araştırma çerçevesinde, Türkiye'de sosyal medya ağlarında yükselen toplumsal ekoloji hareketinin toplumterimbilim ve ağ toplumuna ilişkin alanlararası yaklaşımlar odağında okunması hedeflenmektedir. Bununla birlikte, demokratikleşme yönünde gelişen toplumsal ekoloji hareketlerinin, ilgili çevrimiçi toplulukların terim odaklı kültürel üretim pratikleri üzerindeki netnografik izlerinin sürülmesi amaçlanmaktadır. İlgili çevrimiçi topluluklar etrafında örgütlenen eyleyicilerin, yeni medya uygulamalarıyla nasıl eyleme geçtikleri ve ne tür performans sergiledikleri ile onlarla nasıl toplumsal ve terimsel bir ekoloji hareketi inşa etmeye çalıştıklarını anlamak, ilgili araştırmanın odak noktalarını oluşturmaktadır. Belirlenen amaçlardan hareketle, çalışmaya yön veren araştırma soruları şu şekilde ifade edilebilmektedir: İlgili çevrimiçi topluluklar etrafında yükselen ve toplumsal tahakküme dayalı politikaların aksine, ekolojik toplumsal felsefeyi ve hareketi temsil eden terimlerden söz etmek mümkün müdür? Ya da başka bir deyişle ilgili toplumsal ekoloji terimlerinin, ekolojik bir toplum modeli yaratmak üzere insan ile doğa arasındaki dengeyi yeniden inşa ettikleri söylenebilir mi? İlgili terim odaklı kültürel üretim pratiklerinin, ağ tipi demokratikleşme yönünde gelişen özgürlükçü yeni toplumsal hareketlerin parçası, taşıyıcısı ve sürdürücüsü oldukları belirtilebilir mi?

\section{Kavramsal çerçeve}

Çevrimiçi topluluklarda toplumsal ve terimsel ekoloji hareketinin izlerini sürebilmek farklı bakış açılarının birlikteliğine gereksinim duymaktadır. Çeviribilim alanında yaşanan kültürel dönemeçle birlikte (Baker, 2009: 279) terimbilim alanında meydana gelen toplumsal açılım önem kazanmaktadır. Bu bağlamda, terimleri kullanıldıkları gerçek ortamlarında ele alarak toplumsal boyuta vurgu yapan, terimleri çevreleyen koşulları göz önünde bulunduran toplumterimbilimsel yaklaşım çalışmanın yöntemsel çıkış noktasını oluşturmaktadır. Ekoloji terimlerinin alanlararası dolaşımıyla, söz konusu 
terimler toplumsal ekoloji bağlamında yeniden şekillenmektedir. Toplumsal ekoloji hareketine vurgu yapan bu terimler, sosyal iletişim ağlarında biçimlenen çevrimiçi topluluklarda önemli bir yer tutmaktadır. Bu bağlamda, toplumsal ekoloji hareketine ve ağ toplumuna ilişkin kavramlar çalışmada yol gösterici olmaktadır.

Klasik Kuram adıyla da anılan Wüster’in 1930'larda ortaya attığı Genel Terimbilim Kuramı, terimbilimin kuramsal boyutunu kazanma sürecinde önem taşımaktadır. Kavramdan yola çıkarak terime varan yani adbilimsel bir yaklaşımı benimseyen bu kuramda, terimler metin içindeki işlevleriyle değerlendirilmemektedir. Öte yandan, günümüzde terimlerin kullanıldığı metinler de farklı boyutlara taşınmıştır; klasik metin yerini içeriklere bırakmış, iletişim kanalları genişlemiştir. Bu durum, terimbilim alanında farklı bakış açılarının gelişmesini zorunlu kılmıştır. Terimlerin yer aldıkları uzmanlık alanlarında, bir başka ifadeyle kullanıldıkları bağlam içerisinde değerlendirilmesi terime yönelik birçok bağlamsal bilgiye ulaşmayı da sağlamaktadır. Böylelikle, tek dilli veya çok dilli yürütülen terim çalışmalarının içeriği genişlemekte ve terim çalışmaları metin/içerik üretimine ve metin/içerik çevirisine destek olabilmektedir. Bu noktada, terimbilimin kendine ait araştırma yöntem ve teknikleriyle özerk bir bilim dalı olmasının yanı sıra uygulamalı dilbilim ve özellikle uzmanlık alanı çeviri çalışmalarıyla etkileşim içinde olduğunu vurgulamak yerinde olacaktır. Nitekim terim çalışmaları, çeviri alanında geniş ölçekte yer bulmaktadır (Bowker, 2009: 286).

Terimleri bağlam boyutunda ele alan, terimlerin alanlararası dolaşımına vurgu yapan ve terimbilim alanıyla toplumsal boyut arasındaki bağları öne çıkaran toplumterimbilim (Gambier, 1987, 1993; Gaudin, 1993, 2003), ekoloji terimlerinin alanlararası doğasıyla örtüşen açılımlar getirmektedir. Söz konusu yaklaşım, alanlararası dolaşım, toplumsal yapılar, toplumsal eyleyiciler, toplumsal hareketler, iktidar ilişkileri ve iletişim kanalları gibi toplumsal dinamiklere vurgu yapmakta, terimleri gerçek kullanım ortamları olan söylem boyutunda ele almaktadır (Gambier, 1987:314). Bu noktada, söylemin gerçekleştiği bağlamın ve söylemi gerçekleştiren eyleyicilerin de dikkate alındığını vurgulamak yerinde olacaktır. Terim, sadece dizgesel boyutta değil toplumsal koşullar boyutunda da değerlendirilmektedir.

Ağlarda üretilen ve dolaşıma sokulan toplumsal ekolojiye vurgu yapan içeriklerin çözümlenmesinde terimler üzerinden bir okuma gerçekleştirirken, hiç kuşkusuz içinde bulunulan farklı iletişim kanallarının özellikleri dikkate alınmalıdır. Bu bağlamda, terimlerin izleri, dijital, etkileşimsel, hipermetinsel, hızlı yayılıma sahip, sanal, kullanıcı türevli içerik üretimine dayalı ve mültimedya biçimselliğinin var olduğu ağlarda sürülmektedir. Toplumterimbilimsel yaklaşımın vurguladığı, toplumsal bağlam, farklı iletişim kanallarında üretilen ve dolaşıma sokulan içeriklerle birlikte değişmekte, genişlemekte ve terimbilim araştırmalarında yeni soruşturma biçimlerinin gelişimine zemin hazırlamaktadır (Demirel ve diğerleri, 2018).

Ekoloji terimi, ilk kez 1866 yllında Alman biyolog Ernst Haeckel tarafından şu şekilde tanımlanmıştır: "Ekoloji deyiminden, doğanın ekonomisi ile ilgili olan bilgiler topluluğunu anlıyoruz. Bu bilgiler hayvanların organik ve inorganik çevresi ile olan tüm ilişkilerinin incelenmesini kapsamaktadır. $\mathrm{Bu}$ ilişkiler hayvanlar ve bitkiler arasında ister dostça, ister düşmanca olsun; ister dolayll, isterse doğrudan doğruya bağıntılı bulunsun, bu bilim dalı hepsini kapsamına almaktadır. Kısa bir ifade ile ekoloji, Darvin'in "yaşam için savaş" koşulları olarak ifade ettiği tüm karmaşık ilişkilerin incelenmesi ve araştırılmasıdır” (Çepel, 1983: 9). Kısaca, canlılarla, çevrelerini ve bu iki varlık arasındaki karşıllıkı ilişkileri araştıran bir bilim dalı olarak tanımlanan (Çepel, 1982: 178) ekoloji alanında çalışan araştırmacılar bazen ayrı bazen de birbiriyle örtüssen organizma, popülasyon, topluluk, ekosistem ve biyosfer ana düzeylerinde çalışmaktadır. 

736)

Ekoloji benimsediği yaklaşım ve yöntemleriyle farklı bilim alanlarına nüfus etmekte, bu alanlara ekolojik açılım kazandırmaktadır:

\begin{abstract}
"Bu anlamda birçok bilim dalının sonuna ekoloji getirilerek yeni yeni bilim dalları oluşturulmaya çalışılmaktadır. Örneğin, social ecology, political ecology, physiological ecology, chemical ecology gibi. Bunların dışında ekoloji hayatın diğer alanlarına da girmiş, birçok siyasi, felsefi ve dini düşünceye eklenmiştir. Örneğin, ecological Marxism, ecocapitalism, ecotheology, ecoethics, ecofeminism, libertarian ecology, econationalism, gibi birçok örnek verilebilir" (Sevgi, 2015: 31).
\end{abstract}

Çevrimiçi topluluklarda üretilen ve dolaşıma sokulan içeriklerde ve terimlerde toplumsal ekoloji hareketinin izlerine rastlanmaktadır. Bu nedenle, terimleri toplumterimbilimsel bir yaklaşımla kullanıldıkları ortam ve bağlam açısından ele alabilmek için öncelikli olarak toplumsal ekoloji hareketini ele almak yerinde olacaktır.

\title{
2.1. Murray Bookchin ve toplumsal ekoloji hareketi
}

Ekoloji hareketinin ideolojik, politik ve toplumsal yönleri üzerinde duran Murray Bookchin, insanlığın doğayı sömürmesi ve hükmü altına alması gerektiği yolundaki temel kavrayışın, insanın insan üzerindeki tahakküm ve sömürüsünden kaynaklandığını belirtmektedir (1996: 45). Ekonomi ve iktidar eksenine hapsolan ideolojilerin eleştirisini yapan Bookchin, ekolojiyi salt bir çevre koruma bilinci çerçevesinde değil, bir toplum ve bilim felsefesi, anti-hiyerarşik ve anti-otoriter bir toplum projesi, bir eylem tarzı olarak ele almak gerektiğinin altını çizmektedir. Aslına bakılırsa, mevcut çevreci yaklaşımlar, toplumun temellindeki tahakküm anlayışını sorgulamamakla birlikte sadece tahakkümün neden olacağı tehlikeleri azaltacak teknikler geliştirmekte ve tahakkümün önünü açmayı gözetmektedir (Bookchin, 1996: 62).

Bookchin, özgürlükçü bir bilinç ve eylem tarzına odaklanan toplumsal ekoloji hareketiyle birlikte insan ile doğa arasındaki dengeyi yeniden kuran bir toplum modeli inşa etmeyi hedeflemektedir. Bu çerçevede, eşitlerin eşitsizliği yerine eşit olmayanların eşitliğini savunan toplumsal ekoloji açılımı, doğrudan eylemi, bireyin aktif inisiyatifini, kamusal alanı doğrudan yönlendiren bağımsız, otonom kavrayışı önemsemektedir. Bireyin, buyurgan yasalara boyun eğmeden etik değerlendirme yapabilen öz denetimsel kavrayışının gelişmesini öne koşan toplumsal ekoloji, yaratıcı emek, gönüllü basitlik ve tamamlayıcılık etiği gibi değerleri ön plana çıarmaktadır (Bookchin, 1996: 52). Sözü edilen ekoloji tabanlı yeni toplumsallıklarda, eko-topluluklar ile yerel yönetimlerin karşılıklı eylem, işbirliği ve empati kurması gündeme gelmektedir (Bookchin, 1996: 47). Kendiliğindenlik, hiyerarşik olmayan organik birliktelikler, kendi kendini yaratan, iradeye dayalı üretim biçimleri bu yönde gelişen ekolojik örgütlenme biçimlerini nitelendirmektedir (Bookchin, 1996: 262). Hiyerarşik duyarlılık yerine ekolojik duyarlılığı seçen ekolojik toplumların yeniden yapılanan eyleyicileri, örgütlenme biçimleri ve etik kavrayışları Bookchin'in deyimiyle doğrudan demokrasi anlayışını işaret etmektedir (Bookchin, 1996: 34). Özgürlükçü, bilinçle ve bilimsellikle temellenen akılcı ekolojik toplumsal felsefi sorgulama biçimiyle, Bookchin toplumdaki moleküler ilişkileri dönüştürmeye ve ekoloji alanına ilişkin kavramlara teknik olandan öte anlamlar kazandırmaya çalışmaktadır (2019: 341).

\subsection{A $\breve{g}$ toplumu ve sosyal medya toplulukları}

Toplumsal ekoloji anlayışını kuran kavramlara değindikten sonra sözü edilen bu kavramları ağ toplumu ve bileşenleri çerçevesinde yeniden ele almak farklı sorgulama biçimlerini beraberinde getirmektedir. Bu bağlamda, ağ toplumunu tanımlayan çevrimiçi topluluklar, Jenkins'e (2006) göre ortak ilgi alanları ve beğenileri ekseninde, internet temelli iletişim ortamlarında yakınlaşan bireylerden oluşmaktadır. 
Çevrimiçi topluluklar, bireylerin ve kurumların, kolektif aidiyet ve dayanışma duygularını geliştirmelerini sağlayan bir kimlik inşa ve bilinç yükseltme yeri olarak kavramsallaştırılmaktadır (Jenkins, 2006: 5). Bu çerçevede, kullanıcı türevli içerik üretim sürecinde, amatör, gönüllü, fan, angaje ve dijital aktivist gibi kavramlarla tanımlanan toplumsal eyleyiciler öne çıkmaktadır (Jenkins, 2006: 5). Söz konusu olan eyleyicilerin örgütlenme biçimleri, "hızlı, anlık, içeriğin kullanıcı tarafından üretildiği, gönüllü, katılıma, paylaşıma dayalı, amatör, mobil, etkileşime ve diyaloga açık, yatay, viral, öngörülemez, denetlenemez, gündelik" gibi kavramlar etrafında şekillenmektedir (Şener, 2013: 254). Bu noktadan hareketle, sosyal medya ağlarında biçimlenen ağ temelli yeni toplumsal hareketler, protesto kültürünün, katılımcı üretim pratiklerinin, yatay, akışkan örgütlenme şeklinin ve koreografik, yumuşak liderlik algısının gelişimini desteklemektedir (Gerbaudo, 2014: 257). Toplumsal hareketlerin yenilenen eyleme geçme ve performans sergileme biçimleriyle birlikte, katılımcı demokrasi anlayışı, diyalog kültürü, düşünce, ifade özgürlüğü ve bireyin sivilleşmesi gibi ağ toplumuna ilişkin temel değerler önem kazanmaktadır (Castells, 2013: 21).

\section{Netnografik saha çözümlemesi: "BoMoVu”, "bbOm”}

Araştırma kapsamında önemi vurgulanan ekolojik duruş, ekolojik duyarlılık, eko-topluluk, demokrasi, ayrrmcılık ve şiddet karşıtlğ̆ , toplumsal adalet, eşitlik, katılımcl, paylaşımcı, diyalog kültürü, sosyal farkındalı, gönüllülük, çeviri, çevirmen ve terim gibi anahtar kavramlar odağında gerçekleştirilen arama sonucunda "BoMoVu - Sosyal Güçlendirme için Spor ve Beden Hareketi", "bbOm - Başka bir okul mümkün” adlı çevrimiçi topluluklara ulaşılmaktadır4. Ayrıca düzenli bilgi akışının korunması, çok sayıda aktif üyenin bulunması, web sayfasının etkileşimsel ve hipermetinsel niteliklerle donatılması ve sayfanın sürekliliğinin sağlanması gibi netnografik filtreleme kriterleri de (Kozinets, 2006: 280), ilgili çevrimiçi toplulukların seçiminde rol oynamaktadır.

Netnografik saha çalışması kapsamında, Ocak-Şubat 2019 tarihleri arasında ilgili çevrimiçi toplulukların toplumsal ekolojiye dayanan bir bakışla ürettikleri terimlere yönelik içerik çözümlemesi ve bu topluluklarda örgütlenen eyleyicilerle benimsedikleri toplumsal ekoloji odaklı eyleme geçme ve performans sergileme biçimlerine yönelik çevrimiçi söyleşiler gerçekleştirilmektedir.

\section{1. İçerik çözümlemesi}

İlgili çevrimiçi platformların arayüzlerine yönelik pusu yöntemiyle gerçekleştirilen terim odaklı netnografik içerik çözümlemesi, makro ve mikro olmak üzere iki düzeyden oluşmaktadır. Makro düzeyde, ilgili toplulukların, açlış sayfalarında bulunan amaç, ilkeler ve hedefler sekmesinde, toplumsal ekolojiye yönelik yaklaşımların özellikle de terimlerin izleri aranmaktadır. Mikro düzeyde ise, ilgili toplulukların arayüzlerinde yer alan arama motorları ve etiketler aracılı̆̆ıyla ekolojik duyarlılıkla üretilen içerikler ve terimler ele alınmaktadır.

\subsection{1. "BoMoVu - Sosyal Güçlendirme için Spor ve Beden Hareketi”}

2015 yllında kurulan “BoMoVu - Sosyal Güçlendirme için Spor ve Beden Hareketi” - Türkiye'de, sporcu, dansçı ve performans sanatçılarının uzmanlık alanlarını sosyal faydaya dönüştürmek için oluşturulan bir paylaşım ağıdır. İlgili çevrimiçi topluluğa yönelik yürütülen makro boyuttaki içerik çözümlemesi sonucunda, topluluğun spor ve beden hareketi temelli programlar geliştirmekte olduğu ve sporun içinde

$4 \quad$ Adı geçen çevrimiçi topluluklar, toplumterimbilimsel bir yaklaşımla nefret söylemine karşı bir duruşla oluşturulan içerikler bağlamında "Nefretsiz bir Yaşam Mümkün! Çeviri Odaklı Yaratıcı Aktivist Taktikler” (Demirel ve diğerleri, 2018) adlı makale kapsamında ele alınmıştır. 

736)

varolan ayrımcılıkla mücadele etmeyi hedeflediği gözlemlenmektedir. Bu noktada, topluluğun başlica etkinlik alanları arasında, spor temelli üretim pratikleri ile bireysel ve toplumsal özerkliğin gelişimini desteklemek yer almaktadır. Gönüllülük ilkesinden hareketle yola çıkan "BoMoVu” platformunun hedef kitlesi, çocuklardan, mültecilerden, kadınlardan ve fiziksel engellilerden oluşmaktadır. "BoMoVu” ya ait Facebook sayfası 1326 kullanıcı tarafından takip edilmektedir (bkz. Şekil 1). İlgili topluluk tarafından yürütülen çevrimiçi ve çevrimdışı projeler arasında "Barışa Oyna", "Hareketin Özgür", "Mağdursuz Küfür Atölyesi”, “Eleștirel Beden ve Gönüllü Sporcu Programı” gibi başlıklar yer almaktadır.

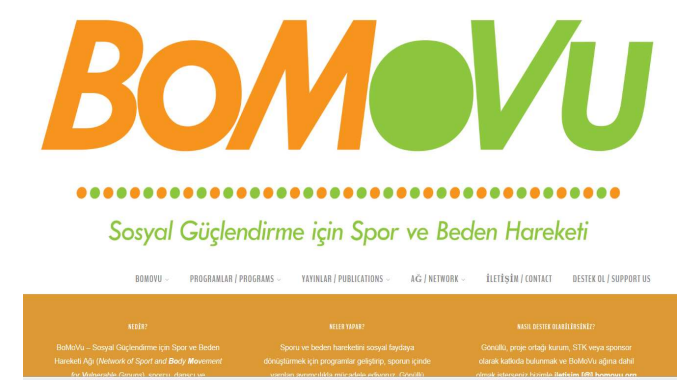

Şekil 1. "BoMoVu” açılış sayfası (http://bomovu.org/)

İlgili topluluğun açılış sayfasında yer alan ya da başka bir deyişle dolaşımda olan etiketlere yakından bakıldığında \#katılımcı hareket, \#yardımsız yardım olmaz!, \#otonomi, \#iletişim ve saygı, \#hak odaklı spor \#bilgi paylaşımı ve \#takdir gibi terim tercihlerinin öne çıktığı gözlenmektedir. Yukarıda sözü edilen Eleştirel Beden başlıklı projenin içeriğinde, sporların inşa ve icra edildiği düzenleri sorgulamak, iktidar ilişkilerini veya dengesizlikleri eleştirel bir bakış açısıyla yeniden ele almak, eleştirel spor programı çerçevesinde hareket hakkını savunmak, ırkçı veya cinsiyetçi davranışlardan arınmış bir spor kulübü yaratmak, ayn zamanda özsavunma teknikleri öğretmek ve cinsiyetçilik mekanizmalarının sorgulandığı bir sporculuk anlayışı geliştirmek gibi değerlerin benimsendiği ortaya çımaktadır (bkz. Şekil 2).

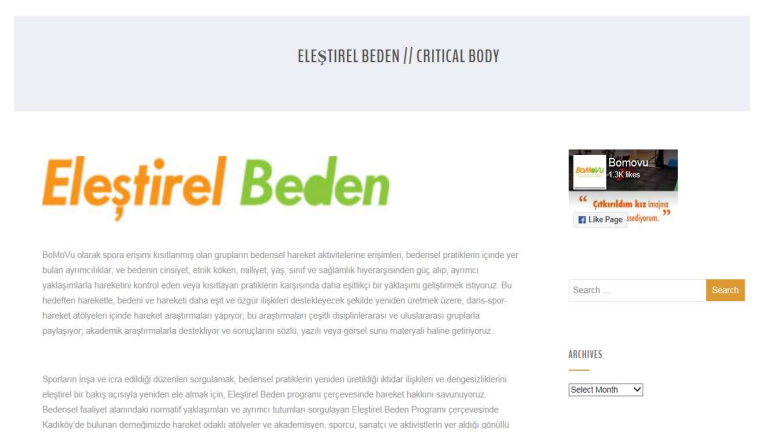

Şekil 2. “Eleştirel Beden” (http://bomovu.org/programlar-programs/elestirel-beden-critical-body/)

Araştırma kapsamında mercek altına alınan bir diğer proje "Barışa Oyna” başlığı taşımaktadır. İlgili projenin amaçları arasında önyargı, ayrtmcılık ve eşit haklar hakkında eğitmenlik desteği vermek, bireysel çalışma deneyimlerini paylaşmak, hoşgörü, kapsayıcılık, eşit haklar, erdem, haz, mutluluk, sevgi ve sayg gibi değerleri oyunlar aracılığıla ön plana taşımak ve çocukların çevreleriyle kurdukları ilişkide sosyal kapsayıcılığı temel alan barışçıl bir ortamın gelişimine katkıda bulunmak gibi alt başlıklara yer verilmektedir (bkz. Şekil 3). 


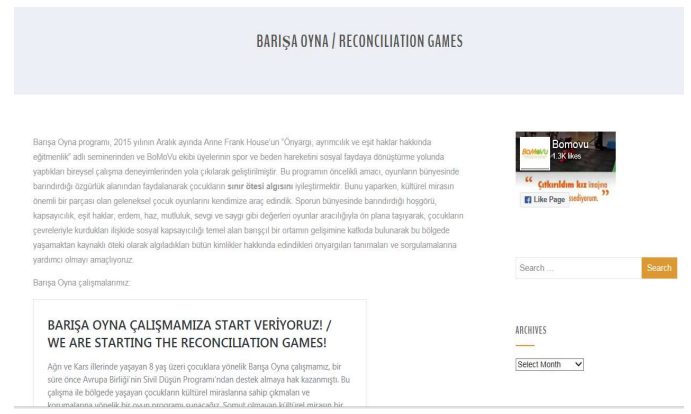

Şekil 3. "Barışa Oyna" (http://bomovu.org/barisa-oyna-reconciliation-games/)

Görüldüğü üzere, “BoMoVu” topluluğunun benimsediği değerlere yönelik terimler ve etiketler odağında gerçekleştirilen toplumterimbilimsel çözümleme sonucunda, topluluğun uyguladı̆̆ pratiklerinde, toplumsal ekoloji felsefesini temel alan ağ temelli yeni toplumsal hareketlerin izlerine tanık olunmaktadır.

\subsection{2. "bbOm - Başka Bir Okul Mümkün"}

"bbOm", alternatif bir okul modeli geliştirmek ve bu modelin uygulandığı okullar açmak amacıyla 2010 yılında kurulan "Başka Bir Okul Mümkün Derneği”ne ait bir sosyal paylaşım ağıdır (bkz. Şekil 4). Katılımcı, barışçıl öğrenme topluluklarının yaratılmasını hedefleyen topluluk, alternatif eğitim, demokratik yönetim, ekolojik duruş ve özgün finansman gibi değerleri benimsemektedir. Gönüllülük esasıyla çalışmalarını yürüten topluluğun, Facebook üzerinde 34.820, Twitter üzerinde 7201, Instagram üzerinde ise 9259 takipçisi bulunmaktadır.

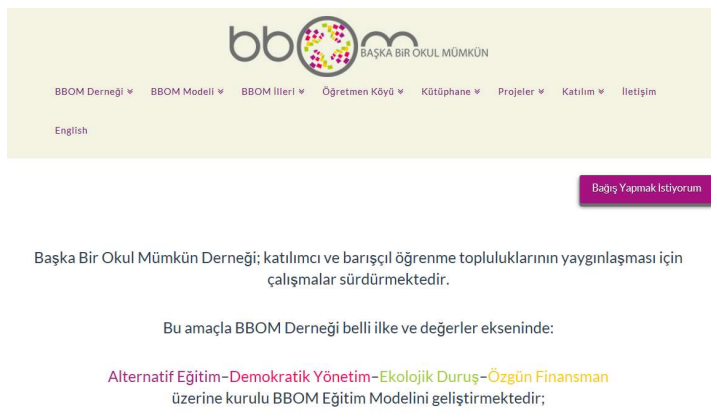

Şekil 4. "bbOm” açılış sayfası (http://baskabirokulmumkun.net/)

Makro boyutta bir okumayla topluluğun ilkeler sekmesini incelediğimizde, topluluk ruhu, eşitlik, toplumsal adalet, düşünce/ifade/hareket/seçim özgürlüğü, dayanışma, çoğulculuk, toplumsal duyarlılık, şiddet karşıthğı, ayrımcılık karşıthğı, ekolojik düşünce, yaratıcllk, üretkenlik, dürüstlük, öz denetimcilik, eleştirellik, bilimsellik, farkındalık, empati gibi toplumsal ekolojik değerlere vurgu yapan terimlerin paylaşıldığı dikkati çekmektedir (bkz. Şekil 5). 

736)

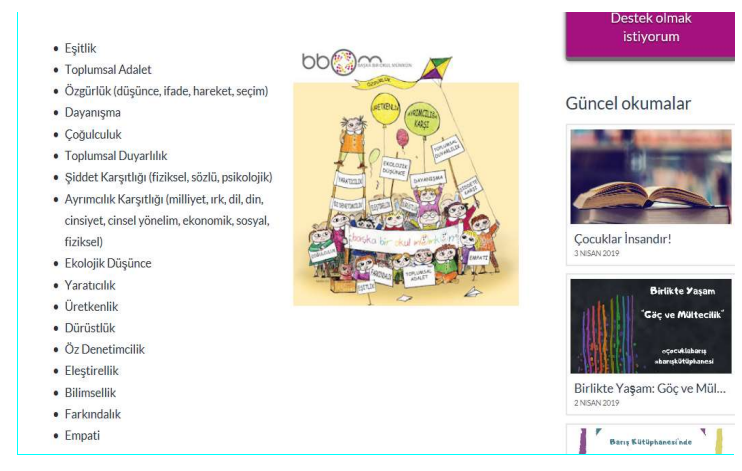

Şekil 5. "bbOm” İlkeri (http://www.baskabirokulmumkun.net/ilkeler/)

Mikro boyutta bir içerik çözümlemesi gerçekleştirdiğimizde, topluluğun ekolojik duyarlılığıyla bağlantılı \#toplumsal barış, \#toplumsal adalet, \#katılımcı, \#barışçıl, \#demokratik ve ekolojik eğitim, \#hak temelli sınıf iklimi ,\#farkındalık, \#empati gibi etiketlerin kullanıldığı görülmektedir. Topluluk, benimsediği değerler doğrultusunda çevrimiçi ve çevrimdışı projeler de yürütmektedir. "Başka Okullar için Öğretmen Eğitimi Projesi”nde "bbOm”; "Çocuk Hakları Sözleşmesi’nde belirlenen hakları hayata geçiren, çocukları birer birey olarak gören ve farklılıklarını tanıyarak kendilerini gerçekleştirmelerine olanak sağlayan, katılımcı demokrasiyle yönetilen, ekolojik dengeye saygılı ve ticari kar amacı gütmeyen okulların kurulması ve yaşaması için öğretmenleri, okul çalışanlarını güçlendirmeyi hedeflediklerini” belirterek toplumsal ekolojiyle bağlantılı değerlere vurgu yapmaktadır. Diğer taraftan, "Doğayla Barış" yaklaşımıyla, topluluk çocukların etrafındaki canlılarla bağ kurarak ekolojik duyarlılığı kazanabilmesi amacıyla bazı araçlar geliştirmektedir (bkz. Şekil 6).

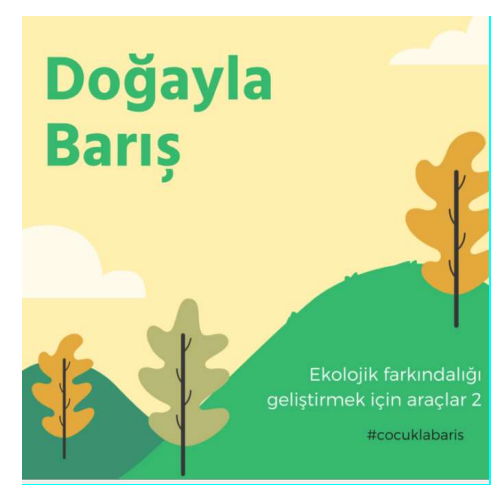

Şekil 6. “Doğayla Barış” (http://www.baskabirokulmumkun.net/dogayla-baris-2/)

Başka Bir Okul Mümkün Derneği’nin önerdiği eğitim modelinde benimsediği temel değerlerden olan ekolojik yaklaşımı eğitim süreçlerine kendi doğallığında bütünleştirmek ve ekolojik farkındalık yaratabilmek amacıyla, topluluk 2019 yılı için "Ekoloji Takvimi” hazırlamıştır (bkz. Şekil 7). 


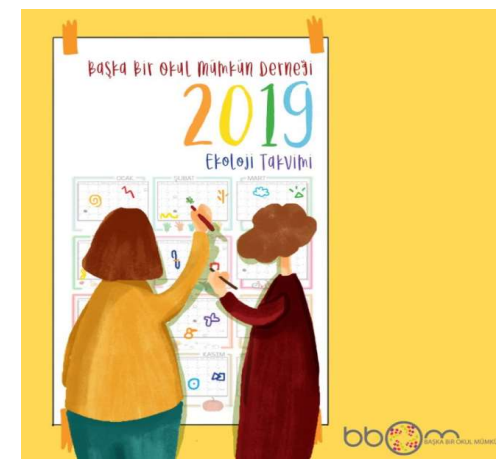

Şekil 7. “Ekoloji Takvimi” (http://www.baskabirokulmumkun.net/2019-ekoloji-takvimi/)

Gerçekleştirilen toplumterimbilimsel çözümleme sonucunda, " $b b O m$ " topluluğu ürettiği ve dolaşıma soktuğu içeriklerde ve terimlerde toplumsal ekolojiye ilişkin değerlere gönderme yapmaktadır. $\mathrm{Bu}$ çerçevede, yaratıcı emek, ekolojik duyarlılık, bağımsız ve otonom kavrayış, demokratik duruş ve öz denetimsel kavrayış gibi toplumsal ekoloji değerlerinin " $b b O m$ " topluluğu tarafından vurgulandığı gözlemlenmektedir.

\section{2. Çevrimiçi söyleşiler}

Netnografik içerik çözümlemesinin ardından, ikinci aşamada ilgili çevirimiçi toplulukları deneyimleyen eyleyicilerle benimsedikleri toplumsal ekoloji odaklı eyleme geçme ve performans sergileme biçimlerine yönelik söyleşiler gerçekleştirilmiş olup, elde edilen veriler tematik çözümleme yöntemiyle irdelenmektedir. Netnografik çözümleme çerçevesinde yürütülen çevrimiçi söyleşilerde, ilgili eyleyicilere profil bilgilerine (eğitim bilgileri ve topluluk içinde yüklendikleri görevler) ve terim odaklı üretim pratiklerinde onları harekete geçiren motivasyon kaynaklarına ilişkin sorular yöneltilmektedir.

"BoMoVu" topluluğunun kurucu başkanı olan ilk görüşmeci eğitimini kültürel çalışmalar alanında gerçekleştirmiş olup kendisini Capoeira tutkunu olarak adlandırmaktadır. Topluluğun kurucu başkanlık görevini üstlenen katılımcı aynı zamanda spor aktivisti ve gönüllü insan hakları savunucusu olduğunun da altını çizmektedir.

İkinci soruya gelindiğinde, aynı katılımcıya "BoMoVu” topluluğunda benimsediği terim odaklı kültürel üretim pratiklerine ilişkin motivasyon unsurlarının neler olduğu sorulmuştur. Bu kapsamda, katılımcının söyleminde öne çıkan vurgu noktaları şu şekildedir: "Bizce, sporda çok haksızlık ve ayrımcılık uygulanıyor. Buna karşı kendimize "spor aktivisti” diyoruz ve bazı gerçeklere ışık tutmaya çalışıyoruz. Aynı zamanda sporun içindeki müthiş gücü sosyal faydaya dönüştürmek için çalışıyoruz. Ağımız vasıtasıyla sporcular ile ihtiyaç sahibi gruplar arasında köprü görevi görmeye çalışıyoruz. Biz çoğunlukla kadın sporcularız, sanırım neden gereksinim duyduğumuzu açıklamaya yeterlidir" (“BoMoVu” topluluğu kurucusu, 13 Ocak 2019)

"Bbom" topluluğunu deneyimleyen ikinci görüşmeci, topluluk içinde çeviri koordinasyon sorumlusu görevini yürütmektedir. Aynı zamanda, Bilimfili ve TED gibi başka sosyal medya ağlarında gönüllü çevirmen olarak yer almaktadır. Yukarıda bahsedilen ve ilgili motivasyon unsurlarının neler olduğunu sorgulayan ikinci soru kapsamında ilgili çevirmenin verdiği yanıtta öne çıkan vurgu noktaları şunlardır: "bbOm Derneği mevcut eğitim sisteminden muzdarip ve kendi çocukları özelinde endişeli ebeveynlerin bir araya gelmesiyle yola çlkmış bir harekettir. Çocukların kendini gerçekleştirebilecekleri, biricik 

736)

oldukları, empatiyle ve barış ile öğrendikleri, alternatif ve demokratik öğrenme ortamlarına duyulan ihtiyaç ebeveynleri, eğitim bilimcileri ve akademisyenleri bir araya getirerek bbOm'nin kuruluşunda etkili oldu. Bugün katılımcı ve barışçı öğrenme ortamlarının yaygınlaşması hayaliyle okullar, öğretmen destek programları, yayınlar gibi alanlarda faaliyet gösteriyoruz. Bununla birlikte çoklu-aktörleri bir araya getiren kapsayıcı, katılımcı bir eğitim sistemi modeli öneriyor ve Türkçe açık veri kaynağı oluşturuyoruz..." (“Bbom” topluluğu çeviri editörü, 5 Şubat 2019)

Çevrimiçi söyleşilerden elde edilen yanıtlar ışığında irdelenen her iki topluluğun, yukarıda kavramsal çerçevede üzerinde durulan eko-topluluklarm nitelikleriyle benzerlik gösterdikleri görülmektedir. Aynı zamanda her iki görüşmecinin söylemlerinde, aktivist duruş benimseme, empati kurma, gönüllü hareketi başlatma, eşitsizliklerin eşitliğini savunma, etik kavrayış geliştirme ve yatay örgütlenme gibi toplumsal ekoloji hareketinin ilkelerini işaret eden değerlere rastlanmaktadır. O halde, netnografik içerik çözümleme sonucunda ulaşılan toplumsal ekolojiyi vurgulayan terimlerin, görüşmecilerin ürettikleri söylemlerinde de vurgulandığı gözlemlenmektedir.

\section{Sonuç gözlemleri}

Sonuç olarak ilgili çevrimiçi topluluklar etrafında yükselen ve toplumsal tahakküme dayalı politikaların aksine, ekolojik toplumsal felsefeyi ve hareketi temsil eden terimlerden söz etmek mümkündür. Başka bir deyişle ilgili ekoloji terimlerinin, ekolojik bir toplum modeli yaratmak üzere insan toplumu ile doğa arasındaki dengeyi yeniden inşa ettiklerine tanık olunmaktadır. İlgili terim odaklı kültürel üretim pratiklerinin, ağ tipi demokratikleşme yönünde gelişen özgürlükçü yeni toplumsal hareketlerin parçası, taşıyıcısı ve sürdürücüsü oldukları görülmektedir. Terimlerin dolaşıma girmesiyle terim içeriklerinin gelişmesi ve dönüşmesi gündeme gelmektedir. Koşullara göre yeniden yapılanan kavramlar ve bu kavramların adlandırılmasında kullanılan terimler dikkat çekmektedir.

Terimlerin boyut değiştirmesi sonucunda terim-içerik ilişkiselliği de yeniden sorgulanmaktadır. Bu da terimlerin dolaşımını toplumterimbilisel bir bakış açısıyla ele almanın gerekliliğini ortaya çıkarmaktadır. Öte yandan, koşulları dikkate alarak, toplumsal bir bakışla terimlere yönelik yürütülecek çalışmalar, terim çalışmasının yürütüldüğü alana yönelik metin üretimine ve o alanda gerçekleştirilecek metin çevirisine katkı sağlamaktadır. Terim çalışmalarının çeviri alanında geniş bir yer bulduğu düşünüldüğünde, terimbilim alanında yürütülecek sistemli çalışmaların çeviri eylemine olumlu katkısı göz önünde bulundurulmalıdır.

Çevrimiçi topluluklara ilişkin ekosisteminin oluşumunda terimlerin katkısı oldukça önemlidir. Bu çerçevede, anti-hiyerarşik ve anti-tahakkümcü duyarlılı̆̆ı, yapılanmayı ve stratejiyi bilinçli olarak geliştiren, işbirliğini, empatiyi, katılımı destekleyen, biyosfer için sorumluluk duygusunu, topluluk ve birliktelik için yeni fikirleri teşvik eden terimlerle karşılaşılmaktadır. Bununla birlikte doğrudan eylemi başlatan, aktivist duruşu benimseyen, tamamlayıcılık etiğini savunan, eleştirirken yeniden yapılandıran, bilimsel olmayan, sahte gerçekliği eleştiren ve gönüllüğ̈̈ yükselten terimlerin önemi vurgulanmaktadır. Sözü edilen eko-toplulukların kurulmasında rol oynayan terimlerin ekoteknolojik yaratım potansiyeline katkıda bulundukları da belirtilebilmektedir.

Son söz olarak elde edilen veriler ışı̆̆ında beden temelli fırsat eşitliğini, cinsiyet temelli barış dilini, eğitim temelli yaratıcı yaklaşımı, bilgi temelli eleştirel kavrayışı benimseyen demokratik ve ekolojik toplumsal terimlerin üretilmesiyle birlikte bu yönde gelişen toplumsal ve terimsel bir ekoloji hareketinden söz etmenin olası olduğu düşünülmektedir. 


\section{Kaynakça}

Baker, M. (2009). Translation Studies. In M. Baker, G. Saldanha (Eds.), Routledge Encyclopedia of Translation Sudies, Second Edition (pp. 277-280). London and New York: Routledge.

Bookchin, M. (2019). İnsanhğ Yeniden Büyülemek. Anti-Hümanize, Mizantropiye, Mistisizme İlkeciliğe Karşı İnsan Ruhunun Savunusu, 1. bs. çev. Gökhan Demir, Dünya Ahtem Öztogay, İstanbul: Sümer.

Bookchin, M.(1996). Ekolojik Bir Topluma Doğru, 1. bs. çev. Abdullah Yılmaz, İstanbul: Ayrıntı.

Bowker, L. (2009). Terminology. In M. Baker, G. Saldanha (Eds.), Routledge Encyclopedia of Translation Sudies, Second Edition (pp. 286-290). London and New York: Routledge.

Castells, M. (2013). İsyan ve Umut Ağları. İnternet Çağında Toplumsal Hareketler, 1. bs. çev. Ebru Kılıç, İstanbul: Koç Üniversitesi.

Çepel, N. (1983). Genel Ekoloji, İstanbul Üniversitesi Orman Fakültesi.

Çepel, N. (1982). Ekoloji Terimleri Sözlüğü, İstanbul Üniversitesi.

Delavigne, V. (1995). Approche socioterminologique des discours du nucléaire in Meta, XL (2), 308318.

Demirel, B. E., Kurmel D. \& Görgüler Z. (Şubat, Mart 2018). Nefretsiz bir Yaşam Mümkün! Çeviri Odaklı Yaratıcı Aktivist Taktikler in Frankofoni, 32, 83-99.

Gambier, Y. (1993). Vers une histoire sociale de la terminologie in Le Langage et l'Homme, XXVIII (4), spécial SOCIOTERMINOLOGIE, 233-246.

Gambier, Y. (1987). Problèmes terminologiques des pluies acides: pour une socio-terminologie in Meta, XXXII (3), 314-320.

Gaudin, F. (2003). Socioterminologie, une approche sociolinguistique de terminologie, Bruxelles: Duculot De Boeck, col. Champs linguistiques.

Gaudin, F. (1993). Pour une socioterminologie. Des problèmes sémantiques aux pratiques institutionnelles, Rouen: col. Publications de l'université de Rouen.

Gerbaudo, P. (2014). Twitler ve Sokaklar. Sosyal Medya ve Günümüzün Eylemciliği, 1. bs. çev. Osman Akınhay, İstanbul: Agora Kitaplığı.

Jenkins, J. (2006). Fans, Bloggers and Gamers. Exploring Participatory Culture, New York: New York University Press.

Kozinets, R. (2002). The Field Behind the Screen: Using Netnography for Marketing Research in Online Communities in Journal of Marketing Research, 39, 61-72.

Kozinets, R. (2006). Click to Connect: Netnography and Tribal Advertising in Journal of Advertising Research, 46 (3), 279-288.

Sevgi, O. (2015). Ecology teriminin Türkçe karşllıları üzerine bir değerlendirme in Avrasya Terim Dergisi, 3 (1), $27-46$.

Şener, G. (2013). Toplumsal Mücadele Alanı Olarak Sosyal Medya. In C. Bilgili, G. Şener (Eds.), Sosyal Medya ve Ă̆ Toplumu 2: Kültür, Kimlik, Siyaset (pp. 253-271). İstanbul: Reklam Yaratıcıları Derneği.

\section{Çevrimiçi kaynaklar}

"BoMoVu - Sosyal Güçlendirme için Spor ve Beden Hareketi”. Ocak-Şubat 2019 tarihinde http:// bomovu.org

“bbOm - Başka Bir Okul Mümkün”. Ocak-Şubat 2019 tarihinde http:// baskabirokulmumkun.org 
736 / RumeliDE Journal of Language and Literature Studies 2020.18 (March)

Example of a socioterminological approach: Circulation of ecology terms in digital networks / D. Kurmel; Z. Görgüler (pp. 725736)

\section{Çevrimiçi söyleşiler}

“BoMoVu - Sosyal Güçlendirme için Spor ve Beden Hareketi” topluluğu kurucusu, 13 Ocak 2019. "bbOm - Başka Bir Okul Mümkün" topluluğu çeviri editörü, 5 Şubat 2019. 